\title{
ECOFRIENDLY APPROACH TO ADSORPTION OF CONGO RED FROM AQUEOUS MEDIA USING CHAFF POWDER FROM JATROPHA CURCAS SEED (ISOTHERM AND KINETIC MODEL)
}

\author{
Musa Yahaya Pudza ${ }^{1^{*}}$ \& Zurina Z. Abidin ${ }^{1^{*}}$ \\ ${ }^{1 *}$ Department of Chemical and Environmental Engineering, Faculty of Engineering, \\ Universiti Putra Malaysia, 43400 Serdang, Selangor, Malaysia. \\ ${ }^{1}$ Department of chemical and Environmental Engineering, University Putra \\ Malaysia, 43400 \\ serdang,Selangor Darul Ehsan, Malaysia. \\ 1* corresponding author zurina@upm.edu.my
}

\begin{abstract}
The Batch process of Adsorption were conducted using Congo red (CR) as the adsorbate and Jatropha curcas seed (chaff) as the adsorbent material. Adsorption kinetics and isotherms analysis were conducted and results obtained confirmed the adsorption process as highly dependent on effects such as; contact time, adsorbent dosage, initial dye concentration and the particle sizes of adsorbate. However, the sorption equilibrium for Congo red dye unto jatropha curcas seed (chaff) was reached within 180 minutes, more so, the Adsorption efficiency was recorded at $82.05 \%$. The process of the experimental sorption kinetics followed a pseudo-secondorder kinetic model while Freundlich isotherm model was best applicable for obtaining the equilibrium of the parameters. These is an effective confirmation and validation of jatropha curcas seed (chaff) application as environmentally friendly and low-cost biomaterial for dye removal from aqueous solutions and industrial effluents.
\end{abstract}

Keywords: Adsorption kinetics; isotherm models; Jatropha curcas; Congo red; Effects.

\section{0 Introduction}

Water resources are indispensable to both natural ecosystem and human developments, thus, wastewater generation cannot be avoided in most industries especially textile factories. The large industrial scale of wastewater purification involves the necessary use of adsorbent that are cheap, in order to minimize the cost of large-scale industrial processes [1]. Much effort has been made to explore the possibility of using various low cost adsorbent [2, 3], Another form of novel and special ecologically friendly coagulants from Jatropha curcas seed and press cake was investigated with high yield result for sustainable coagulative performance and its competence to remedy wastewater [4], Jatropha presscake for the biosorption of $\mathrm{Zn}$ (II) [5], adsorption of mythylene blue on waste potato peels and chemically modified Chaetophora Elegans algae respectively [6, 7], sequestration of reactive dyes using saccharomyces cerevisiae [8], use of Algal biomas to remove copper (Cu (II)) from aqueous solution [9], there also was a report on the use of animal dung to treat industrial wastewater [10], With all the emphasies nowadays being made on environmentally feasible resources to replace toxic and unsustainable approaches to water treatment, Efforts have been made recently by Oday et al., [11] to produce a form of chitosan mushroom to replace aluminium sulfate popularly known as alum, $\left(\mathrm{KAl}\left(\mathrm{SO}_{4}\right)_{2} .12 \mathrm{H}_{2} \mathrm{O}\right)$ which have negative environmental effects on plants and animals [12]. Thus, there is an increasing interest in applying a low cost, environmentally sustainable and readily available material for effective water and wastewater treatment [13]. More so, the elimination of colour from wastewater is paramount before discharging it into any larger water bodies, in view of the aforementioned it becomes a daunting prerequisite as far as natural controls and welfare of the considerable number of 
animals is concern. It is necessary to find a suitable and cost-effective ways of safeguarding and maintaining a pristine water appearance. This research focus upon utilizing a waste from agricultural material (jatropha curcas) and its usage in the efficient adsorption of colour from the synthetic (Congo red).

Adsorption is one of the powerful treatment processes of dyes removal from aqueous medium. Adsorption techniques are very successful method to remove colored organics [14]. Adsorption as a physicochemical technique is suitable in wastewater treatment; it mixes the wastewater and the permeable material powder or granules. By this technique, Pollutants in the wastewater are effortlessly and promptly adsorbed and expelled on the surface of the permeable material [15]. The process of adsorption involves separation of a substance from one phase into another phase by adherence at the surface on it. Mostly there are two (2) methods of adsorption which are physisorption and chemisorptions. These methods take place when the molecules in the liquid (or gas) phase become attached to the surface of the solid as a result of attractive forces at the solid surface (adsorbent) by overcoming the kinetic energy of the liquid contaminant (adsorbate) molecules. Physisorption occur when there are differences in energy or electrical attractive forces [16].

Nonetheless, to the best of our knowledge this experiment has not been carried out in this proportion. More so, its capacity gives it a novel approach to waste water treatment of textile effluent containing dye (Congo red) and other similar dyes of the same and slight variable attributes.

\subsection{Materials and Methods}

\subsection{Method of Preparing chaff from Jatropha curcas seed}

The Jatropha curcas seeds were taken from Kaduna, North central Nigeria. The fruit was manually harvested, dried under the sun and preserved in a moisture proof container at $25^{\circ} \mathrm{C}$ $35^{\circ} \mathrm{C}$ and relative humidity of $40-50 \%$ for two months. Jatropha curcas seed was then deshelled manually and grinded. $2 \mathrm{~kg}$ grounded seeds was sieved using the sieves with different pore sizes $(0.5 \mathrm{~mm}, 1 \mathrm{~mm}$ and $2 \mathrm{~mm})$, after which the chaff was collected and was grinded and sieved to same pore sizes. Then it was kept in an air tight container until further use.

\subsection{Formulation of Dye solution}

Congo red a sodium salt dye obtained from R \& M marketing, Essex, U.K has a molecular formula C32H22N6Na2O6S2 with IUPAC name of disodium-4-amino-3-[4-[4-(1-amino-4sulfonato-naphthalen-2-yl)diazenylphenyl]phenyl]diazenyl-naphthalene-1-sulfonate. $1000 \mathrm{ml}$ stock solution was made by dissolving $1.0 \mathrm{~g}$ of Congo red in one liter distilled water. To obtain various solutions, different concentrations was prepared by diluting the stock solution with suitable volume of distilled water. More so, all the reagents to be used was of analytical grade except otherwise stated. 


\subsection{Batch biosorption Studies}

These experiments were conducted under room temperature $\left(25^{\circ} \mathrm{C}\right)$. A $250 \mathrm{~mL}$ stopper cork conical flasks was filled with $100 \mathrm{~mL}$ of adsorbate at different initial concentration (20$100 \mathrm{ppm}$ ), Contact time (3-180 minutes), $\mathrm{pH}$ ( $\mathrm{pH}$ meter model jenway 3305, England) ranging from 2 to 12, adsorbent dose (0.5-2.5g), Orbital sharker was set at a constant speed of 120rpm (Model Heidolph, incubator 1000, Germany). Following is the final concentration of dye recorded by a double beam UV Spectrophotometer (Model GENESYS-10-UV) at a wavelength of $485 \mathrm{~nm}$. The amount of biosorption at equilibrium, qe $(\mathrm{ml} / \mathrm{g})$, was computed using equation (3.1) and the percentage removal of dye was calculated using equation (3.2).

$q e=\frac{\left(C_{0}-\mathrm{Cf}\right) v}{M}$

$\mathrm{q}=$ equilibrium dye concentration on adsorbent at any time $(\mathrm{mg} / \mathrm{g})$

$\mathrm{M}=$ mass of the adsorbent used $(\mathrm{g})$

$\mathrm{V}=$ volume of the dye solution $(\mathrm{L}$

$\%$ Removal $=\frac{\text { Co-Cf }}{\text { Co }} \times 100$

Where;

$\mathrm{Co}=$ Initial dye concentration in sample $(\mathrm{mg} / \mathrm{L})$

$\mathrm{Cf}=$ equilibrium dye concentration in sample $(\mathrm{mg} / \mathrm{L})$

\subsection{Results and Discussion}

\subsection{Characterization of Powdered Chaff}

\subsubsection{Fourier Transform infrared (FTIR)}

The mechanism for adsorption by powdered chaff of jatropha depends on the chemical reactivity of functional groups at the surface. This reactivity creates an imbalance between forces at the surface compared inside the body, thus leading to molecular adsorption by the van der Waals force. Knowledge on surface functional groups would give information to the adsorption capability of the produced powder chaff. FTIR spectra were collected for qualitative characterization of surface functional groups of the chaff of jatropha seed and figure 1 below shows functional groups of the powder chaff. From the figure below, the peaks at $3312.83 \mathrm{~cm}^{-1}-3781.49 \mathrm{~cm}^{-1}$ in spectra of jatropha chaff were assigned to the alcohol group $(-\mathrm{OH})$ stretching which have strong, sharp and broad intensity. The band at $2855.56-$ $3008.21 \mathrm{~cm}^{-1}$ can be attributed to the acid group $(\mathrm{O}-\mathrm{H})$ stretch which has a strong and broad intensity. The amide and ester group which contain a carbonyl $(\mathrm{C}=\mathrm{O})$ is assigned at the peak $1660.16 \mathrm{~cm}^{-1}$ and $1745.79 \mathrm{~cm}^{-1}$ respectively which have a strong intensity. The adsorption peak at $1000 \mathrm{~cm}^{-1}-1300 \mathrm{~cm}^{-1}$ was assigned to ester group (C-O) stretching which has two (2) or more band intensity. 


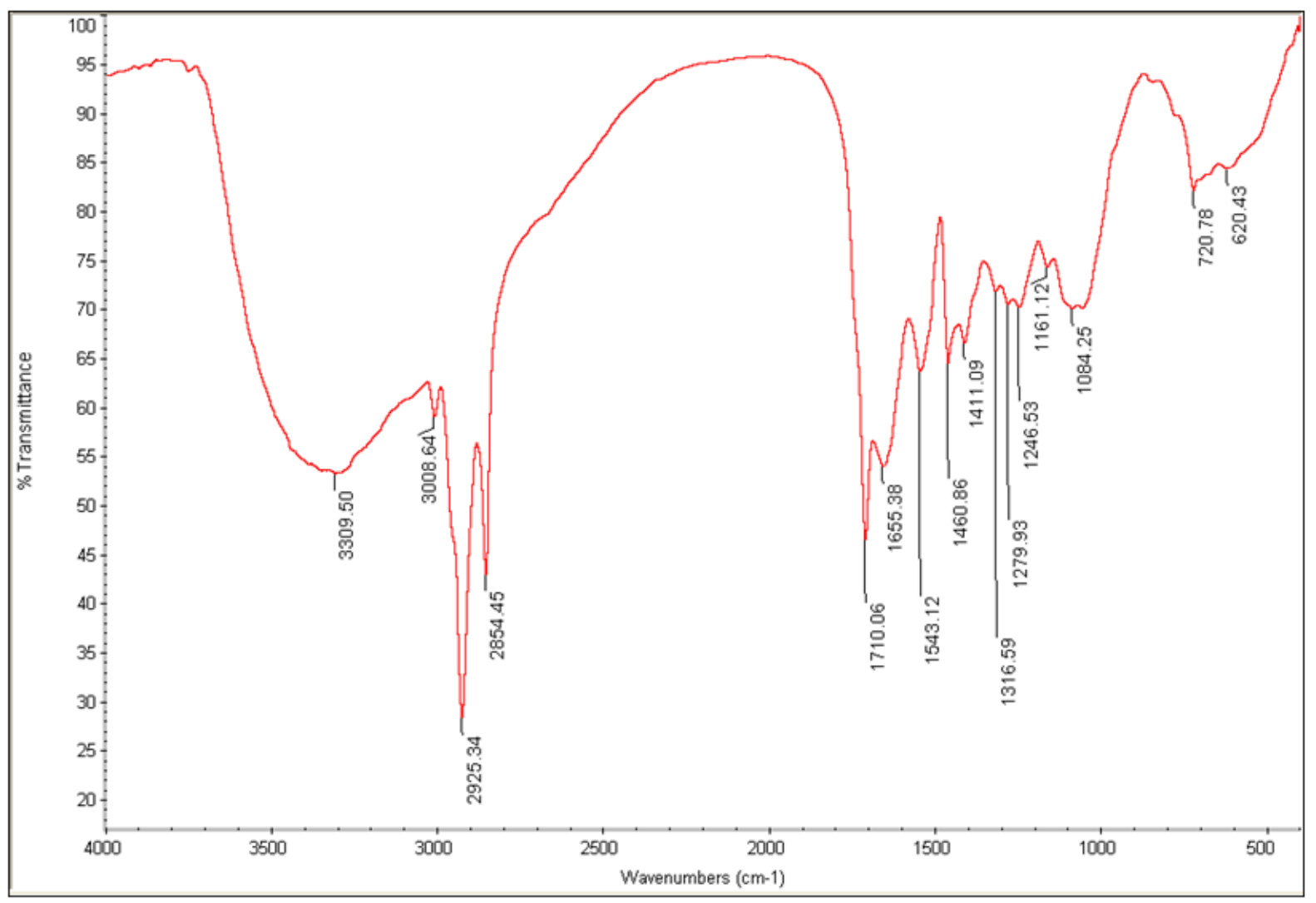

Figure 1a. FTIR Analysis (Before)

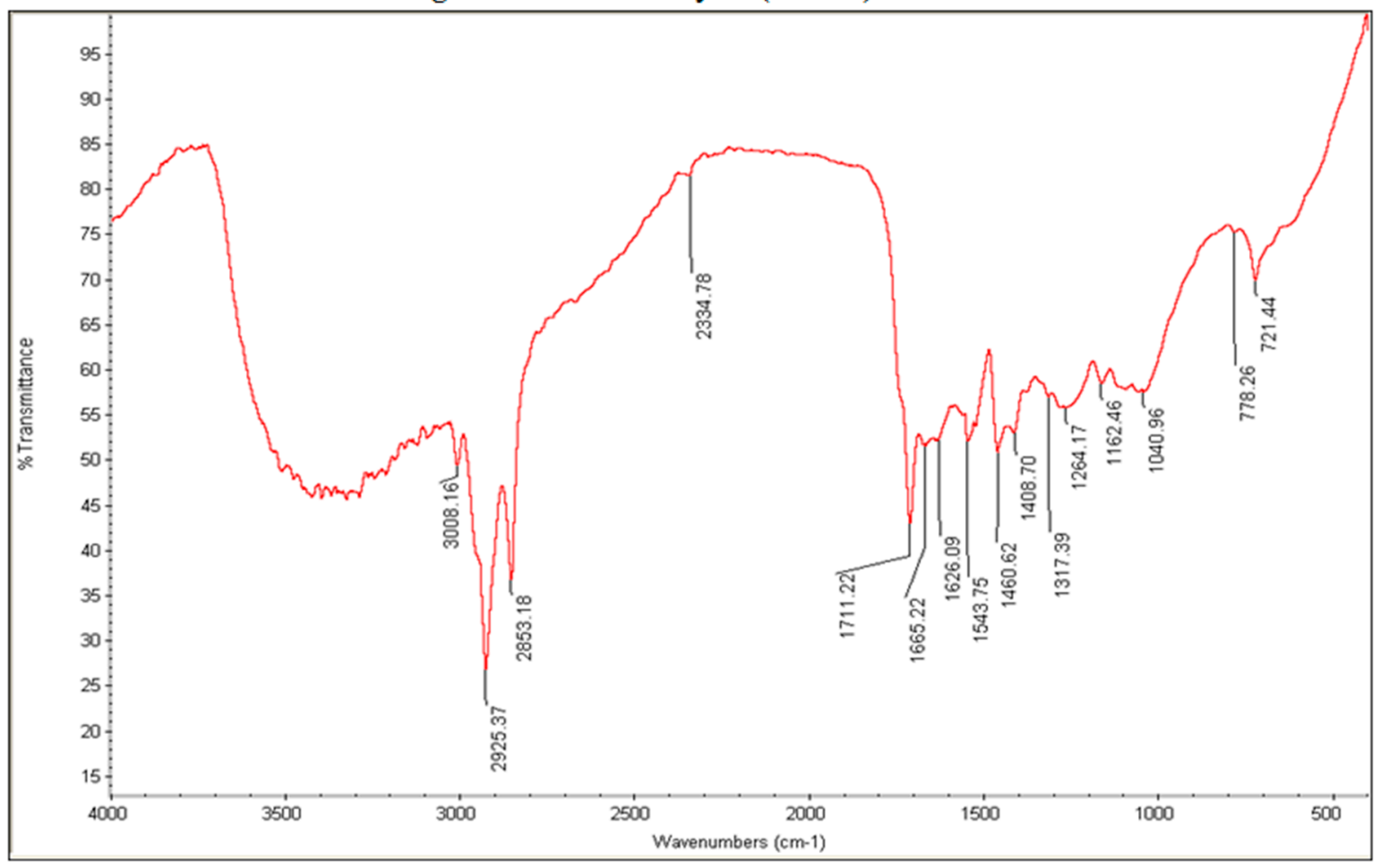

Figure 1b. FTIR Analyses (After)

From the FTIR analysis in figure 1(a,b), it is concluded that the powder chaff from jatropha seed have a broad and strong $(\mathrm{O}-\mathrm{H})$ stretching which indicate the presence of strong hydrogen bonds associated with alcohols and carbonyl. Thus, the (carbonyl, acid amino and phenolic hydroxyl) acts as a chemical bonding agent for chemisorptions which indicated that 
adsorption of Congo Red on powdered chaff involved electrostatic attraction especially interaction between dye and the (carboxylate and phenolic hydroxyl)groups on the powdered chaff.

\subsubsection{Scanning Electron Microscopy (SEM) Analysis}

The SEM image of chaff of Jatropha curcas seed showed an irregular surface with a low and non-porous surface area (figure 2 (a)). The biosorption of Congo red leads to multiple attachment on the rough surface and occupation of pores (Figure 2 (b)). Pores in solid medium like adsorbents, may have properties such as shape, location, connectivity, and surface chemistry.

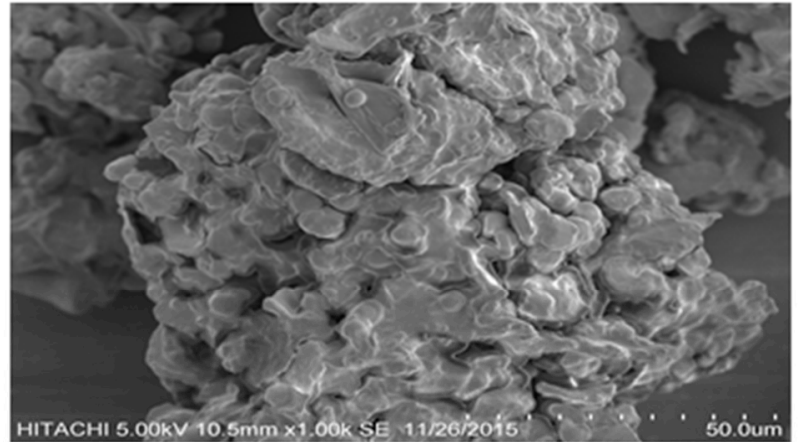

(a)

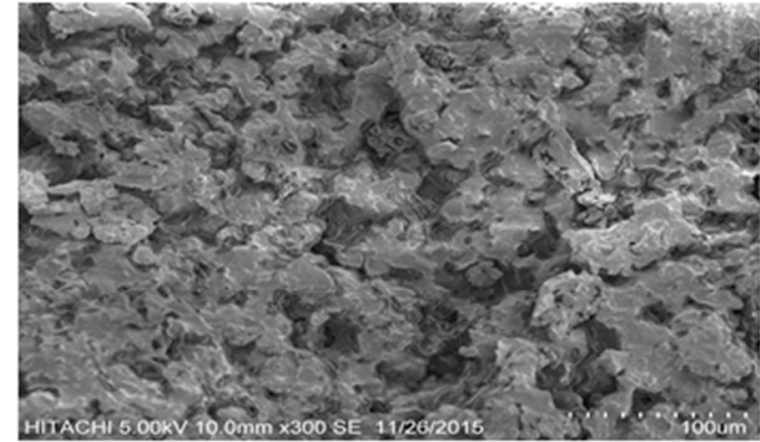

(b)

Figure 2: SEM images for chaff of Jatropha curcas seed (magnification $5.00 \mathrm{kv} 10.5 \mathrm{~mm} * 300 \mathrm{SE}$, $100 \mathrm{um}$ ) (a) before, and (b) after biosorption.

\subsection{Effect of Initial Dye Concentration on Congo red Adsorption}

The adsorption of CR onto the jatropha curcas seed was studied at different initial dye concentration of (CR) stock solution. The experiment was carried out with different initial dye concentrations between $20 \mathrm{mg} / 1$ to $100 \mathrm{mg} / 1$ of the stock solution of CR and the equilibrium adsorption was attained in three (3) hours at constant dosage of adsorbent (1g) as in figure 3

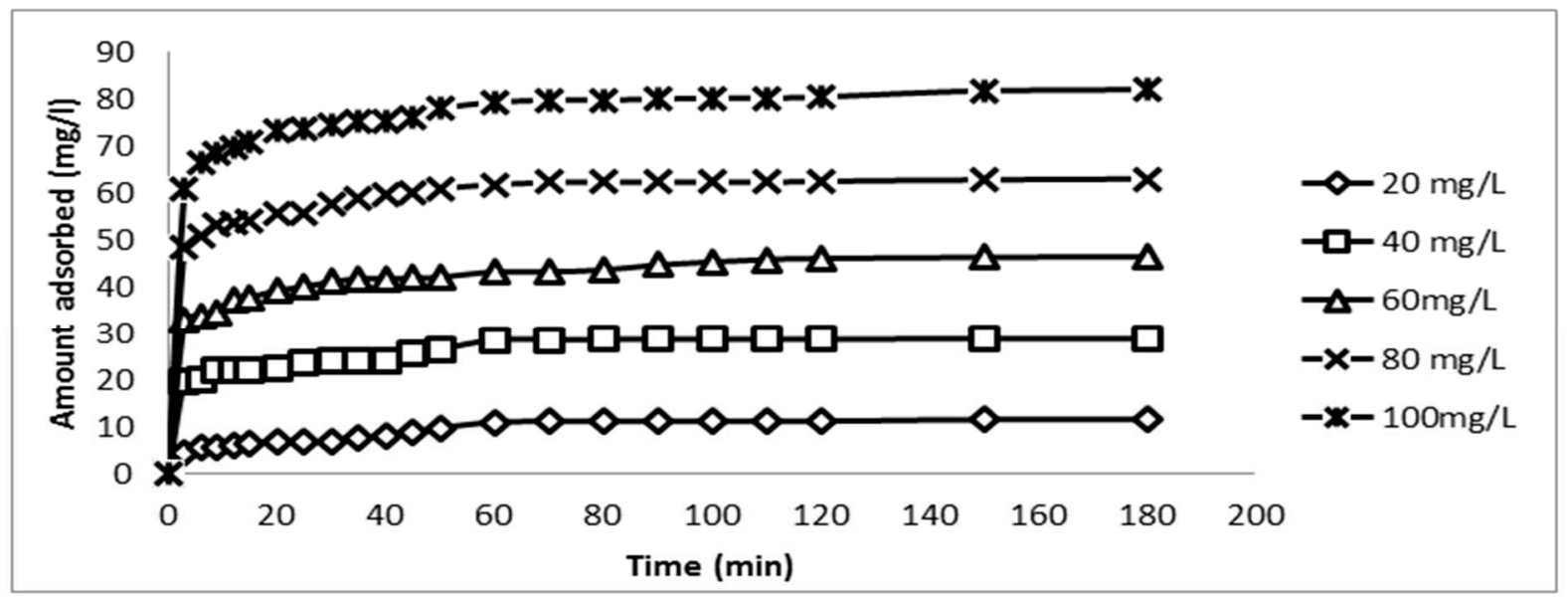

Figure 3. Effect CR Concentration on the amount absorbed by jatropha curcas seed

The result shows that the amount of CR adsorbed per unit mass of adsorbent increases from $20.44 \mathrm{mg} / \mathrm{l}$ to $39.22 \mathrm{mg} / \mathrm{l}$ as the concentration increase from $20-100 \mathrm{ppm}$. When the 
concentration of $\mathrm{CR}$ increased, the driving force of concentration gradient was stronger because of the higher adsorption capacity.

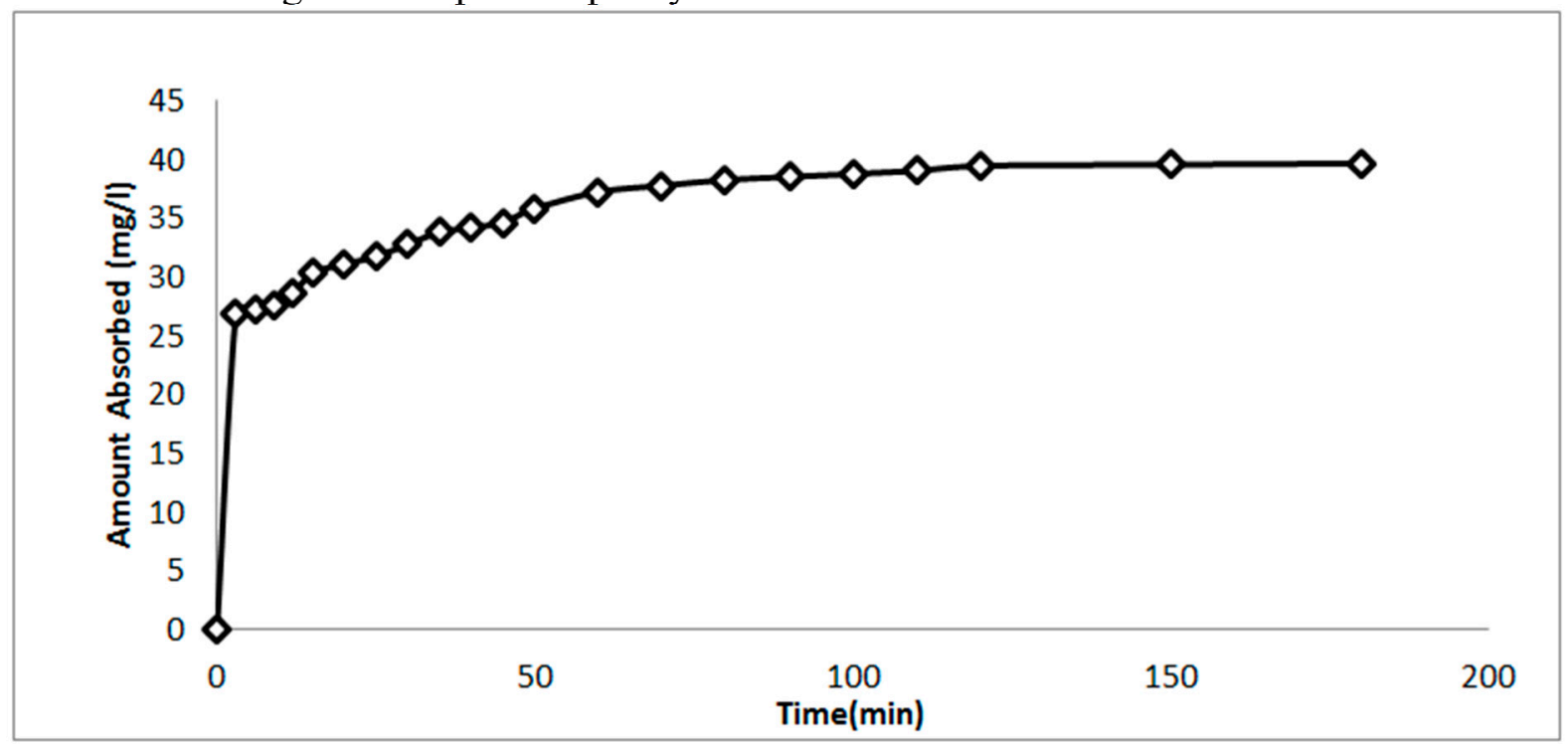

Figure 4: Effect of contact time and Dye Concentration.

The effect of contact time and dye concentration on the removal of CR shown in figure 4 above .when the concentration of dye increased, adsorption became slower with increased contact time. This is owed to the strong attractive forces between the dye molecule and the adsorbent, fast diffusion onto the external surfaces was followed by fast pore diffusions into the intra-practical matrix to attain rapid equilibrium [17]. Besides, the slowness in adsorption rate is owed to the restriction by the solute to diffuse through the adsorbent. The percentage of dye removal increased constantly as the time increased from 3-180 minute until it reached the equilibrium and the rate of the removal is higher in the beginning due to the larger surface area that is available on the adsorbent.

\subsection{Effect of pH on Congo red Adsorption}

The effect of initial $\mathrm{pH}$ of dye solution on the percentage removal of $\mathrm{CR}$ was studied by conducting the various initial $\mathrm{pH}$ under equilibrium contact time (3 hours), concentration of CR solution $(50 \mathrm{mg} / \mathrm{l})$ and dosage of adsorbent $(1 \mathrm{~g})$. The results are as shown in figure 5 . The dye removed by jatropha curcas (chaff) was lower at high $\mathrm{pH}$ and the optimum $\mathrm{pH}$ was attained at $\mathrm{pH} 3$. This is because, at $\mathrm{pH} 3$, the positive charges on the amino acids that make up the protein molecules dominate. Most of the amino acids present in Jatropha curcas. Protein has isoelectric point (pI) values from 3.2 to around 11. Hence, it is expected that most of the amino acids will have positive charges at $\mathrm{pH} 3$.As an amphoteric molecule; the charge on the protein is owed to the $\mathrm{pH}$ values. The main mechanism is adsorption and neutralization of charges. Jatropha as an adsorbent agent works effectively under highly acidic conditions, though it is relevant for treating industrial wastewater with a variable $\mathrm{pH}$ [18]. As a result, the percentage removal increased from $4.09 \%$ to $84.02 \%$ at ph of 3 and 11 respectively. 


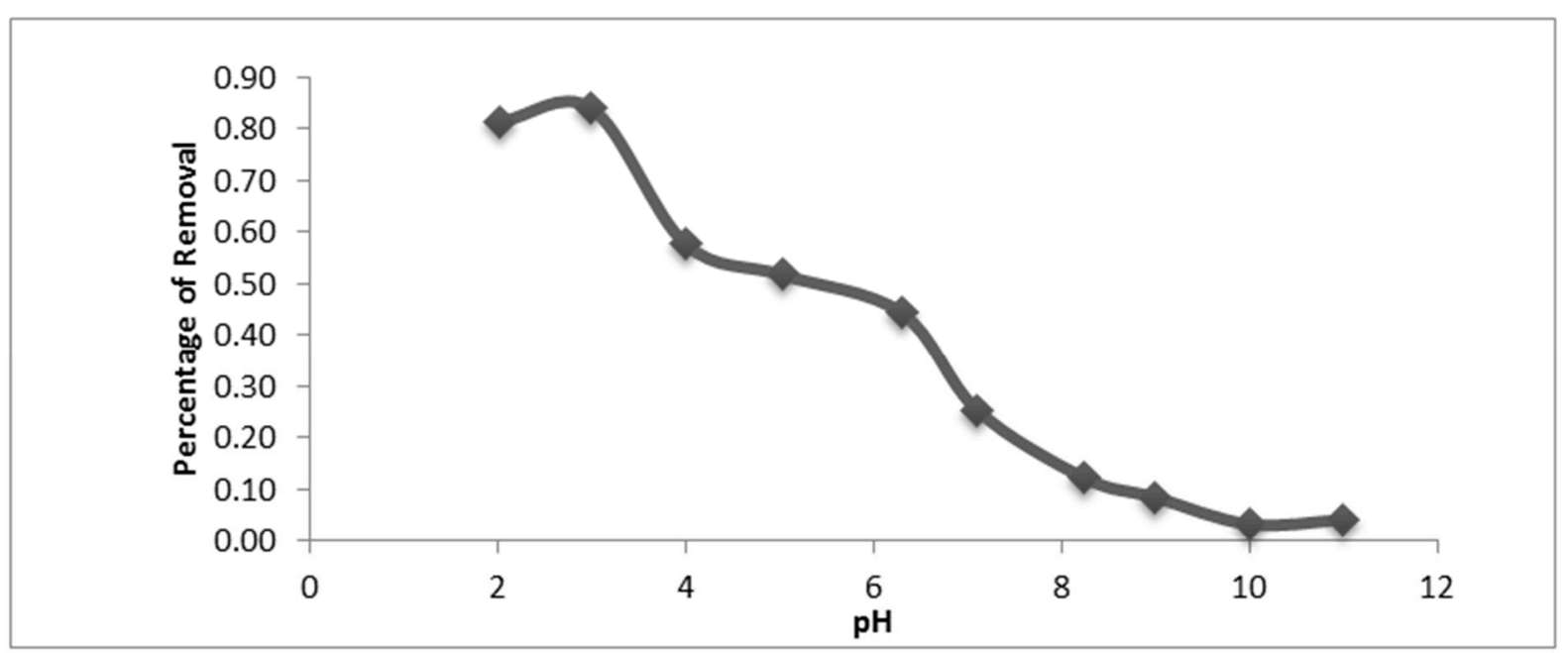

Figure 5: Percentage Removal of CR at different $\mathrm{pH}$.

\subsection{Effect of Dosage on Congo red Adsorption}

The amount of jatropha curcas seed (powder chaff) used to remove CR was varied from $0.25 \mathrm{~g}$ to $1.5 \mathrm{~g}$ for investigation of the relationship between adsorbent dosages on the amount of adsorbate removed.

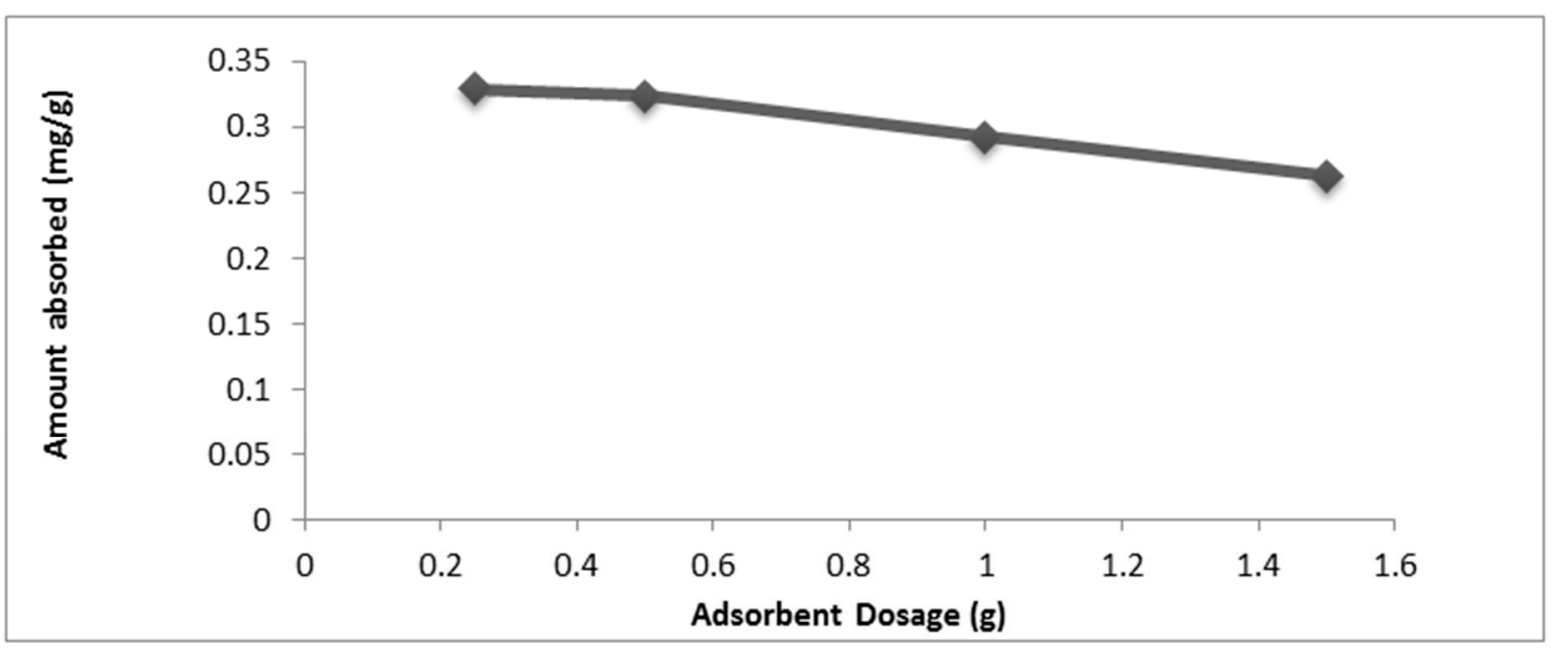

Figure 6. The effect of adsorbent dose to the uptake of CR (Initial concentration: 50ppm, Adsorbent volume $150 \mathrm{~mL}$, Agitation speed: $120 \mathrm{rpm}$, contact time: 180 minutes; at $\lambda \mathrm{max}=485 \mathrm{~nm}$ )

The influence of sorbent dose on adsorption enables the determination of highest equilibrium adsorption capacity. In this study, when the adsorbent dose was increased from $0.5 \mathrm{~g}$ to $2.0 \mathrm{~g}$, there was a significant decrease in equilibrium of Congo red (CR) uptake. This is shown in figure 6 above, an increase in adsorbent dose results to an increase in the available adsorption sites, but this resulted to overlap of adsorption sites. Increased overlap of adsorption sites 
therefore inhibits adsorption of more CR dye molecules hence lower adsorption. Previous studies for effect of adsorbent dose on CR dye adsorption by [19] on eucalyptus wood and on jujuba seeds have shown similar results.

\subsection{Effect of particle size on Congo red adsorption}

Adsorption has been observed to be dependent on the number of adsorbent sites hence surface area of the adsorbent. The influence of particle sizes on adsorption of Congo red (CR) onto Jatropha curcas seed (powdered chaff) is shown in figure 7.

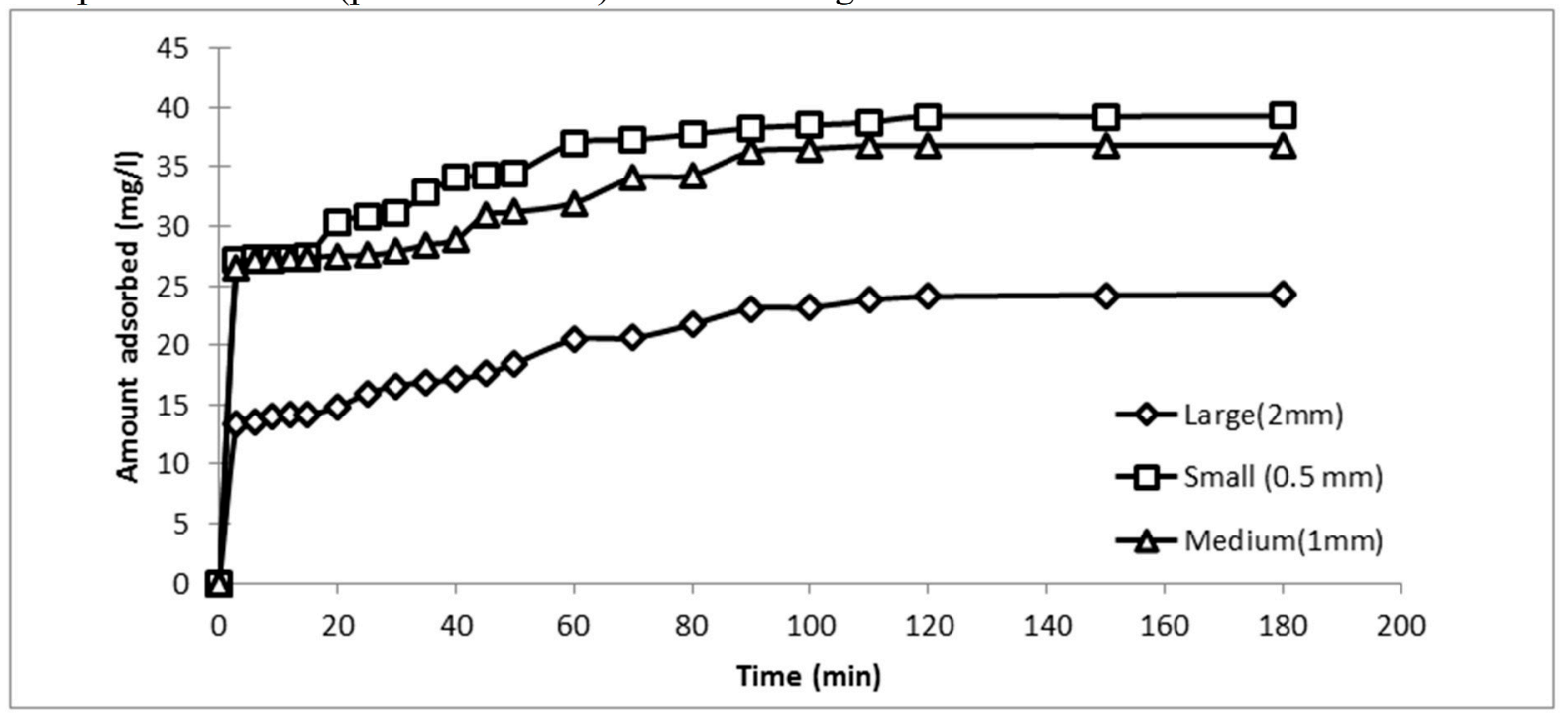

Figure 7 Effect of Particle Size for Congo red Adsorption onto jatropha curcas.

\subsection{Effect of temperature on Congo red adsorption}

Temperature changes the amount of dye molecules in solution, viscosity and the surface characteristics of adsorbent. This particular influence of temperature on the adsorption of Congo red (CR) dye onto jatropha curcas was observed, within temperature range of $303 \mathrm{~K}$ to $333 \mathrm{~K}$. The temperature variation of CR dye adsorption on Jatropha curcas seed is shown in Figure 8;

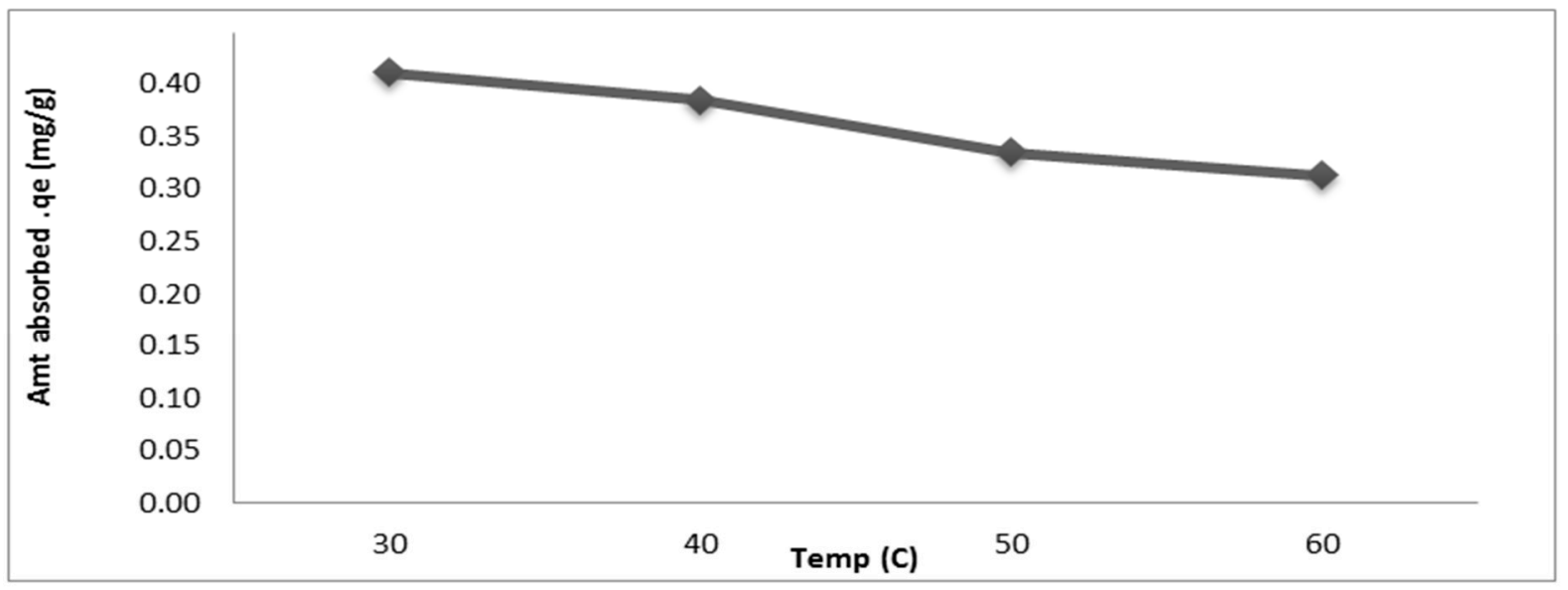

Figure 8. Effect of Temperature for Congo red Adsorption onto Jatropha curcas seed 
As shown in Figure 8 above, the adsorption of CR dye onto the adsorbents under study is exothermic and therefore a physical process $[20,21]$ an increase in temperature weakens intermolecular hydrogen bonding and Van der Waal forces between dye molecules and functional groups on adsorbent surface. Similar observations have been reported on spent brewery grains on adsorption of Methylene blue [22]

\subsection{Adsorption Equilibrium}

The equilibrium adsorption data for various initial Congo red (CR) concentrations was modeled using the Langmuir isotherm to determine whether the process occurs through monolayer coverage. The Langmuir isotherm model is a linear plot of the total amount of dye that is being adsorbed (qe) against the equilibrium concentration $(\mathrm{Ce})$ for $\mathrm{CR}$ in figure 9, the equilibrium adsorption of CR increases with the initial dye concentration, this confirms the adsorption process to be dependent on the initial concentration. Initially, the adsorption isotherm of dye molecules increases substantially, suggesting a strong affinity of the dye molecules for the surface sites on jatropha.

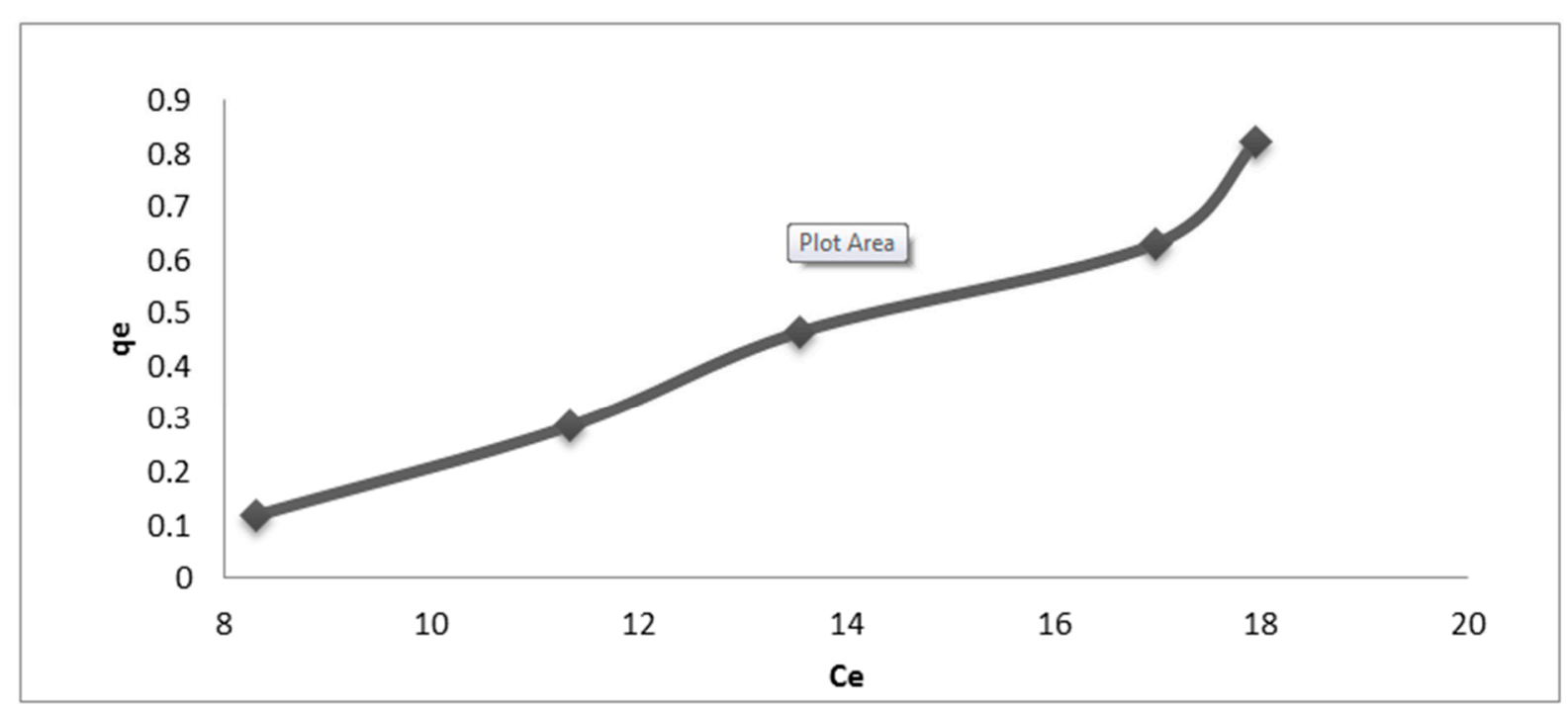

Figure 9: Equilibrium adsorption isotherm of CR dye onto Jatropha.

\subsubsection{Langmuir Isotherm}

Figures 10 shows the Langmuir isotherms for Congo red adsorption onto chaff of jatropha curcas seed. The values of the Langmuir constant $\mathbf{K}_{\mathbf{L}}$ and the monolayer capacity $\mathbf{q}_{\mathbf{m a x}}$ can be evaluated from three forms of Langmuir adsorption models. This can be done either ways; From the intercept and the slope of the linear plot of the experimental data $(\mathrm{Ce} / \mathrm{qe})$ versus $\mathrm{Ce}$ or $(1 / \mathrm{qe})$ versus $(1 / \mathrm{Ce})$ or qe versus $(\mathrm{qe} / \mathrm{Ce})$. 
Table 1: Parameters and separation factors $\left(\mathrm{R}_{\mathrm{L}}\right)$ for the three Langmuir forms for CR adsorption onto powdered chaff from jatropha curcas seed

\begin{tabular}{|l|l|l|l|l|l|}
\hline Adsorbent. & $\begin{array}{l}\text { Langmuir } \\
\text { Equation } \\
\text { Form. }\end{array}$ & $\mathbf{I}_{\max }(\mathbf{m g} / \mathbf{g})$ & $\mathbf{K}_{\mathrm{L}}$ & $\mathbf{R}^{2}$ \\
\hline $\begin{array}{l}\text { Powdered chaff from } \\
\text { jatopha curcas seed }\end{array}$ & 1 & -22.2974 & -0.04538 & 0.8274 \\
& 2 & -18.5087 & -0.04874 & 0.9465 \\
& 3 & -24.2337 & -.0 .04431 & 0.9673 \\
\hline & & & & \\
\hline
\end{tabular}

From comparing the three Langmuir forms in Table 1, it was validated that the Langmuir equation has higher correlation coefficients $\mathrm{R}^{2}$ than other Langmuir forms which is an indication that the Langmuir (form 3) is best compared to Langmuir equation (form $1 \& 2$ ). The highest initial of dye concentration $\mathbf{C}_{\mathbf{0}}$ used in the adsorption isotherm studies was $50 \mathrm{mg} / \mathrm{L}$ and the corresponding values of parameter $\mathrm{R}$ are in the range $0.0600-0.0900$. All the R-values for the adsorption of CR on powdered chaff of jatropha curcas seed are found to be less than one (1) and greater than zero (0), which shows that the adsorption process is favourable, Which is due to the effect of the pore diffusion sorption phenomenon.

\subsubsection{Freundlich Isotherm}

The plot of $\ln \mathrm{q}_{\mathrm{e}}$ against $\ln \mathrm{C}_{\mathrm{e}}$ as shown in figure 11 below gives straight lines which can obtain $1 / \mathrm{n}$ from slope and $\mathrm{K}_{\mathrm{F}}$ intercept. The slope $(1 / n)$ from 0 to 1 is a measure of adsorption intensity or surface uniformity, becoming more uniform as its value gets closer to zero [23]. If the value of exponent $n$ was greater than $1(n>1)$ then the adsorption represent favourable adsorption conditions [24] The figure 11 below shows the linear plot of $\ln q_{e}$ against $C_{e}$ and the values of $n$ and $\mathrm{K}_{\mathrm{F}}$ are listed in table 2 for jatropha curcas. From the graph, the value of $\mathrm{K}_{\mathrm{F}}$ can be obtained from the intercept and $1 / \mathrm{n}$ from slope.

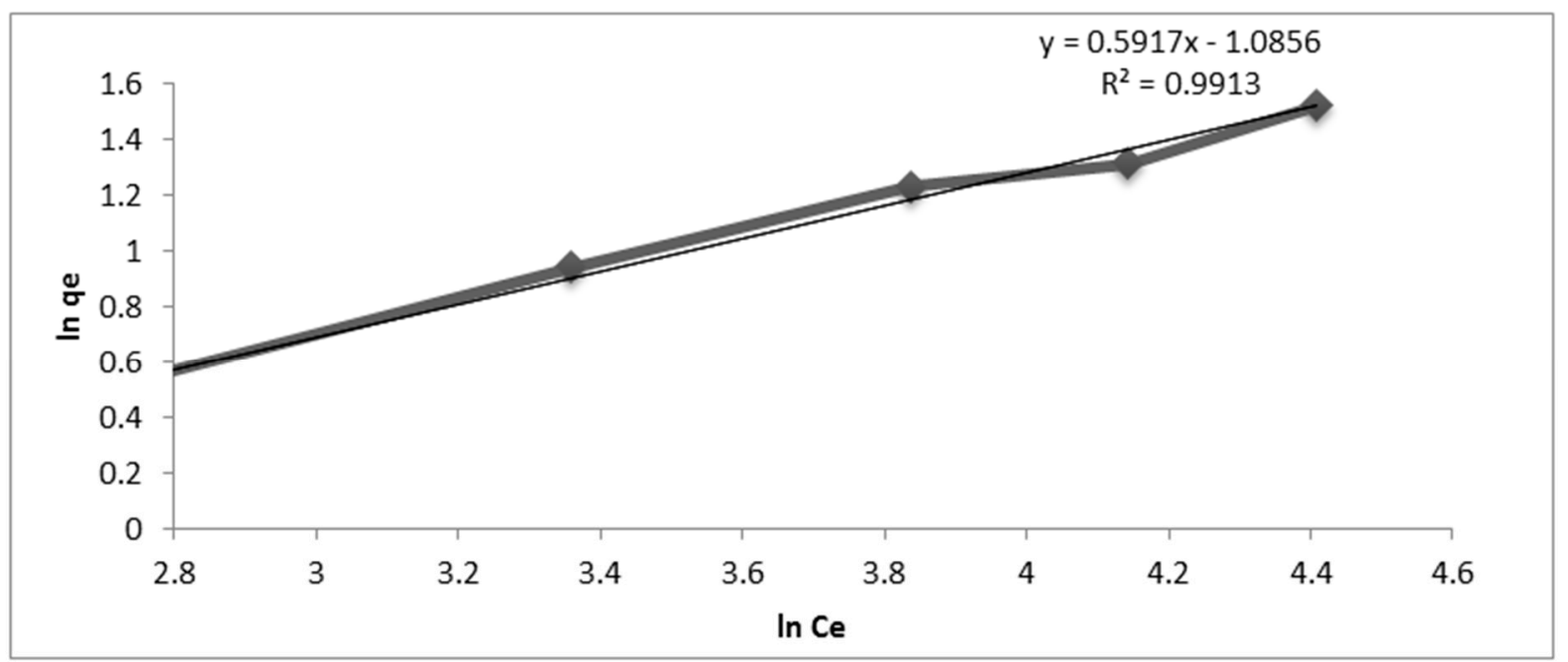

Figure11. Freundlich Isotherm for Jatropha 
In the Table 2 the values of Freundlich parameters were obtained from the linear correlations between values of $\ln$ qe versus $\ln \mathrm{Ce}$. The Freundlich isotherm parameters along with the $\mathrm{K}_{\mathrm{F}}$ and $\mathrm{n}$ were found as 0.082 and 1.69 , respectively $\left(\mathrm{R}^{2}=0.9913\right)$. The value of $1 / \mathrm{n}$ is 0.592 it indicates the heterogeneity of jatropha surface, the slope $1 / \mathrm{n}$ ranging $(0-1)$ is a degree of adsorption magnitude or surface uniformity, which becomes uniform as its values approaches zero [25].

Table 2: Freundlich isotherm parameters for $\mathrm{CR}$ adsorption onto jatropha

\begin{tabular}{|c|c|c|c|c|}
\hline Isotherm & n & $1 / n$ & $\mathrm{~K}_{\mathrm{F}}\left((\mathrm{mg} / \mathrm{g})(\mathrm{L} / \mathrm{mg})^{1 / n}\right)$ & $\mathrm{R}^{2}$ \\
\hline Freundlich & 1.69 & 0.592 & 0.082 & 0.9913 \\
\hline
\end{tabular}

\subsection{Adsorption Kinetics}

The adsorption experiment was carried out at concentration of 20-100 ppm, at $\mathrm{pH} \mathrm{3}$, adsorbent dose of $1 \mathrm{gram} / 50 \mathrm{ml}$ and contact time varied between 3 to 180 minutes. The experiment followed pseudo-second-order.

\subsubsection{Pseudo-Second-Order kinetic model}

In this model, Lagergren equation was used in the determination of rate constant for biosorption of Congo red. A graph of $t$ /qt against $t$ was plotted, in order to show the trend of this model. Figure 12 below shows a linear form of this model at varying Congo red concentration on chaff of jatropha curcas seed. The coefficient $\mathrm{R}^{2}$ for this kinetic model at an initial concentration of $20 \mathrm{mg} / \mathrm{l}$ was 0.9855 and 0.9996 at $100 \mathrm{mg} / 1$. the calculated values of adsorption capacity ( $\mathrm{q}_{\mathrm{cal}}$ ) become higher than the first model. The value ranges from $12.36094 \mathrm{mg} / \mathrm{g}$ to $82.6446 \mathrm{mg} / \mathrm{g}$ at $20 \mathrm{mg} / \mathrm{l}$ and $100 \mathrm{mg} / 1$ respectively. Based on the observed calculated and experimental values it can be concluded that, adsorption of Congo red follows pseudo-second-order kinetic model.

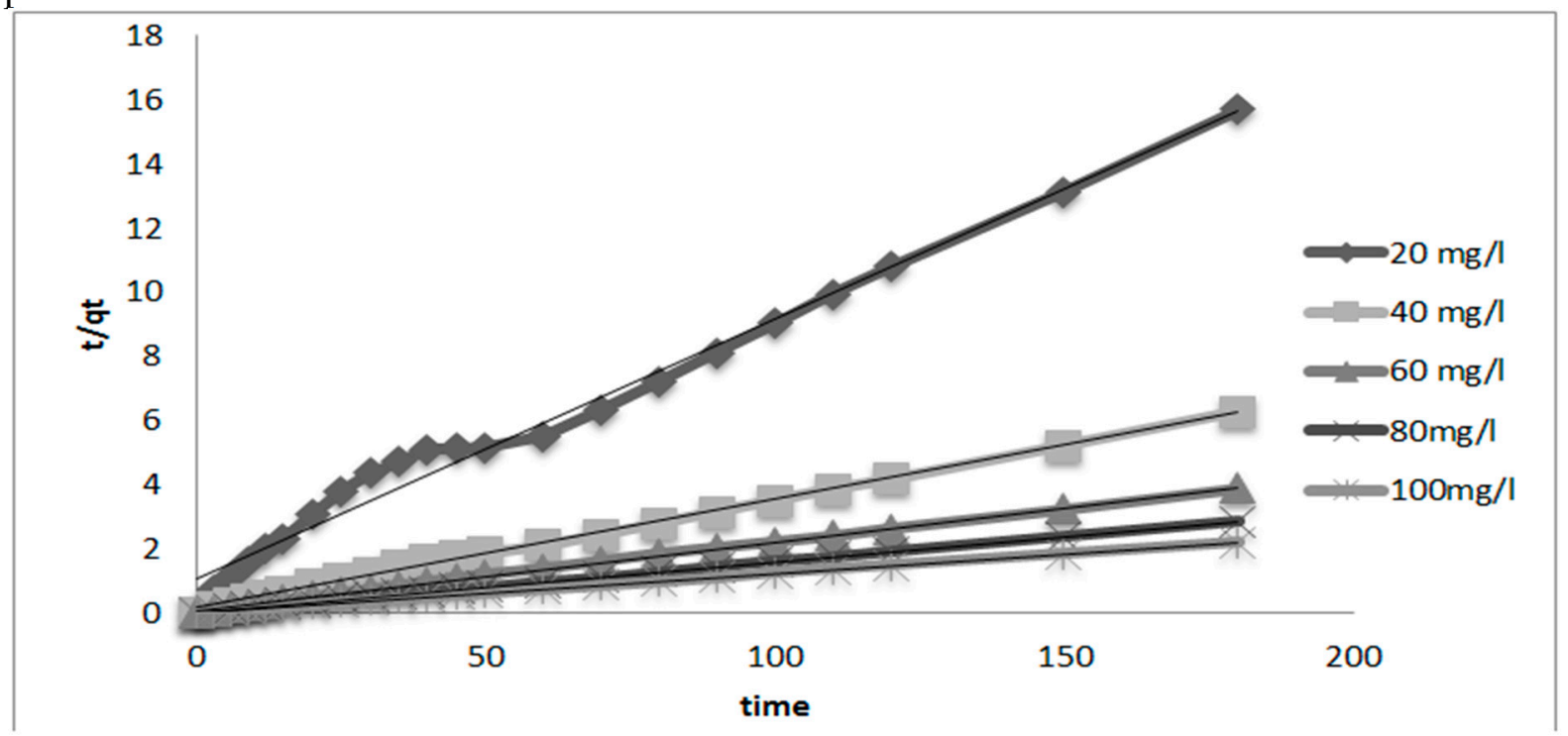

Figure 12: Initial dye concentration second order kinetics study.

Pseudo-second-order rate constant $\left(\mathrm{k}_{2}\right)$, and $\mathrm{q}_{\mathrm{e}}$, and qual were obtained from the slope and intercept of the graph in figure 11 . The values are given in Table 3. 
Table 3 Adsorption kinetic parameters of Congo red on chaff of jatropha curcas seed

\begin{tabular}{|c|c|c|c|c|}
\hline & Second & er model & & \\
\hline $\mathrm{C}_{0}(\mathrm{mg} / \mathrm{l})$ & $\mathrm{R} 2$ & $\mathrm{qe}_{\mathrm{cal}}(\mathrm{mg} / \mathrm{g})$ & $\mathrm{qe}_{\mathrm{exp}}(\mathrm{mg} / \mathrm{g})$ & $\mathrm{K}_{2}\left(\min ^{-1}\right)$ \\
\hline 20 & 0.9855 & 12.36094 & 11.47 & 0.006544 \\
\hline 40 & 0.9979 & 29.5859 & 28.76 & 0.00114 \\
\hline 60 & 0.999 & 46.9484 & 46.44 & 0.00045369 \\
\hline 80 & 0.9998 & 63.6943 & 63.01 & 0.00024649 \\
\hline 100 & 0.9996 & 82.6446 & 82.05 & 0.0004641 \\
\hline
\end{tabular}

From table 3, it can be seen that the qe cal values calculated from pseudo-second-order kinetic model shows compatibility trend as compared to the experimental uptake ones, qexp. However, $\mathrm{R}^{2}$ value for each concentration from $(20-100 \mathrm{mg} / \mathrm{l})$ in pseudo-second-order kinetic model are higher than those obtained in pseudo-first-order kinetic model and none of the values is below 0.99 with the lowest being 0.9855 at $20 \mathrm{mg} / 1$ initial dye concentration. This phenomenon reveals that the adsorption process does rightly fits in to the pseudo-secondorder process.

\subsection{CONCLUSION}

The experimental findings suggest that chaff of jatropha curcas seed is potential costeffective adsorbents for treatment of wastewater generated from Congo red. Inference can be reached and concluded from the effects of parameters, such as Initial Dye concentration, Adsorbent dosage, $\mathrm{Ph}$ of solution and Particle size. The adsorption kinetics data followed pseudo-second-order kinetic model with high correlation coefficient approaching unity. This is an indication of chemisorptions and electrostatic interaction.

\section{Acknowledgement}

Thanks to the Technician of pilot plant and biochemical laboratory, Department of Chemical and Environmental engineering, UPM.

\section{REFERENCE.}

1. R. Wladyslaw, and P. Wojciech, Theoretical description of the kinetics of solute adsorption at heterogeneous solid/solution interfaces: On the possibility of distinguishing between the diffusional and the surface reaction kinetics models. Applied Surface Science (2007): 5827-5840.

2. K.A. Piyushi, M. G. Subramanian, and Dastidar. Adsorptive removal of dye using biochar derived from residual algae after in-situ transesterification: Alternate use of waste of biodiesel industry. J. Env. $\operatorname{Mgt}$ (2016): 187-197.

3. K. Singh, B. Chandra, and M. Gautam, Developement of Inexpensive Adsorbent from Agro-Waste for Phenol Adsorption. J. sci. \& Ind. 
Research (2016): 444-451.

4. Z.Z. Abidin, N. Madehi, and R. Yunus, Coagulative behavior of Jatropha curcas and its performance in wastewater treatment. Environ Prog Sustain (2017): 126-35.

5. Z.Z. Abidin, S.M.A. Mohd, M.Y. Harun, B.N. Abu, Biosorption of Zn (II) from aqueous solution by jatropha curcas press cake. $J$ sci. \& Ind. Research (2014): 191-194.

6. A.O. Yalcyn, G.P.S. Selda, and A. Nevin, The Adsorption of Methylene blue from aqueous solution by using waste potato peels; equilibrium and kinetic studies. J. Sci. \& Ind. Res (2012): 817-821.

7. M. Farah, and E.J. Mouhiaddine, Biosorption of methylene blue on chemically modified Chaetophora Elegans algae by carboxylic acids. $J$. Sci. \& Ind. Res (2013): 428-434.

8. E.S. Bireller. P. Ayater, S. Gedikli. And A. Cabuk, Removal of some reactive dyes by untreated and pretreated sacchar0myces cerevisiae, an alcohol fermentation wate. J. Sci. \& Ind. Res (2012): 632-639.

9. N.R. Bishnoi, P. Anju, and Garima, Biosorption of copper from aqueous solution using algal biomas. J. Sci. \& ind. Res (2004): 813-816.

10. V. Sheoran, R. Chaudharr, and N.K. Tholia, Treatment of Industrial Waste by Organic wastes. J. sci. \& Ind. Res (2013): 255-260.

11. A. Oday. Z.Z. Abidin, I. Azni, K. Suryani, and S.A. Mothanna, A novel biocoagulant agent from mushroom chitosan as water and wastewater therapy. Environ Sci Pollut Res (2017): 12-17.

12. B.O. Rosseland, T.D. Eldhuset, and M. Staurnes, Environmental effects of Aluminium. Environ Geochemistry and Health (1990): 17-27.

13. E.K. Aysegül, Y. Saadet, P. Seher, Y. Hatice, and B. Cem, Dye Removal From Textile Waste Water Through The Adsorption By Pumice Used In Stone Washing. AUTEX Research Journal (2015): 158-163.

14. E. Erdem, N. Karapinar, and R. Donat, The removal of heavy metal cations by natural zeolites. J. Colloid and Interface Science 280 (2004): 309-314.

15. W. Zongping, H. Kai, and L. Zizheng, Textile Dyeing Wastewater Treatment,Advances in Treating Textile Effluent. InTech, Shanghai, China: InTech, 2011.

16. G. André, and A.B. Nancy, Investigation of the range of validity of the pairwise summation method applied to the calculation of the surface roughness correction to the van der Waals force. Surface Science (2016): 28-40.

17. A. Aydin. and D.Y. Bysal Remediation of Heavy metals in the Environ. 
FLorida: CRc press, Taylor and Francis group., 2006.

18. Z.Z. Abidin, N.Y Ismail, R. Yunus, I.S. Ahamad, A. Idris, A preliminary study on Jatropha curcas as coagulant in wastewater treatment. Environ. Technol. 32 (9) (2011): 971-977.

19. C.D. Mane and G.H. Babu, Kinetic and equilibrium studies on the removal of Congo red from aqueous solution using Eucalyptus wood (Eucalyptus globulus) saw dust. J. of the Taiwan Institute of Chem. Eng. (2013): 8188 .

20. B. Benguella, and H. Benaissa, Effects of competing cations on cadmium biosorption by chitin. Colloids and Surfaces A: Physicochemical and Eng. Aspects (2002): 143-150.

21. S. Chegrouchea, and A. Bensmailib, Removal of Ga(III) from aqueous solution by adsorption on activated bentonite using a factorial design. Water Research (2002): 2898-2904.

22. H.A. Chanzu, J.M. Onyari, and P.M. Shiundu, Biosorption of malachite green from aqueous solutions onto polylactide/spent brewery grains films:kinetic and equilibrium studies. J Polym Environ (2012): 665 - 672.

23. S.B. Olugbenga, A.O. Mary, and M.O. Abimbola, Sorption Studies Of Lead Ions Onto Activated Carbon Produced From Oil-Palm Fruit Fibre. Stem Cell (2010): 14-29.

24. C.R. Namasivayam, R.T. Jeyakumar, and D. Yamuna. Dye removal from wastewater by adsorption on waste $\mathrm{Fe}(\mathrm{III}) / \mathrm{Cr}(\mathrm{III})$ hydroxide. Waste Manage (1994): 643-648.

25. N. Atar, A. Olgun, and F. Çolak, Thermodynamic, equilibrium and kinetic study of the biosorption of basic blue 41 using Bacillus maceran. Eng. Life Sci (2008): 499-506. 